\title{
Latvijas Universitātes Raksti LU e-resursu repozitorijā: pieejamība un izmantošana
}

\section{Scientific Papers of the University of Latvia in University of Latvia E-resource Repository: Availability and Usage}

\author{
Ilga Rampāne \\ Latvijas Universitātes Bibliotēka \\ E-pasts: Ilga.Rampane@lu.lv
}

Rakstā ir sniegta informācija par LU Rakstu sērijas krājumu atspoguḷojumu tiešsaistes vidē - LU e-resursu repozitorijā. Repozitorijs nodrošina informācijas ilglaicīgu saglabāšanu un izmantošanu atvērtā piekḷuvē, veicina LU zinātnisko sasniegumu pieejamību un pētniecības attīstību. Rakstā ir apskatīts rakstu krājumu sadalījums pa kolekcijām un zinātņu nozarēm, meklēšanas iespējas repozitorija saskarnē, kā arī meklēšanas iespējas, izmantojot dažādas meklētājprogrammas. Raksta noslēgumā dota LU Rakstu sērijas krājumu izmantošanas statistika pa zinātnes nozarēm un repozitorija kolekcijām.

Atslēgvārdi: atvērtā piekḷuve, informācijas pieejamība, meklēšana, izmantošanas statistika, repozitorijs, zinātniskie raksti.

\section{Summary}

The article provides information on inclusion of the University of Latvia Scientific Papers' collections in the online environment - the University of Latvia e-resource repository. UL e-resource repository provides long-term open access to the full texts, promotes and distributes the scientific achievements of the UL, contributing to research development. This article provides a review of collections in different scientific fields, as well as repository search options in interface, as well as using different search engines. Article also contains a review of Scientific Papers' usage in different scientific fields and repository collections.

Keywords: open access, information availability, information searching, repository, scientific papers, usage statistics. 
Latvijas Universitātes (turpmāk - LU) Rakstu sērija ir būtiska Latvijas zinātnes un kultūras vēstures sastāvdaļa. Rakstos ir apkopotas dažādu paaudžu Universitātes pētnieku atziņas, atklājumi un citi pētniecỉbas rezultāti, kuriem ir liela nozīme kā LU, tā arī augstākās izglìīibas un pētniecỉbas attīstībā valstī. Lai nodrošinātu starptautiski atzīstamu zinātnisko darbību un zinātniskā darba rezultātu plašu, starptautisku publiskošanu un paaugstinātu LU reputāciju un prestižu, LU Bibliotēka digitalizēja tās krājumā esošos LU Rakstu sērijas krājumus, kuri nebija "dzimuši elektroniski”. Tika digitalizēts 651 sējums, kas bija atrodams LU Bibliotēkas krājumā (1. att.). Rakstu krājumu digitalizācijas uzsākšana un nepieciešamība nodrošināt ilglaicīgu informācijas saglabāšanu un atvērtu piekḷuvi pilnteksta informācijai paātrināja LU e-resursu repozitorija izveidi 2011. gadā (LU rīkojums Nr. 1/155, 19.05.2011.).
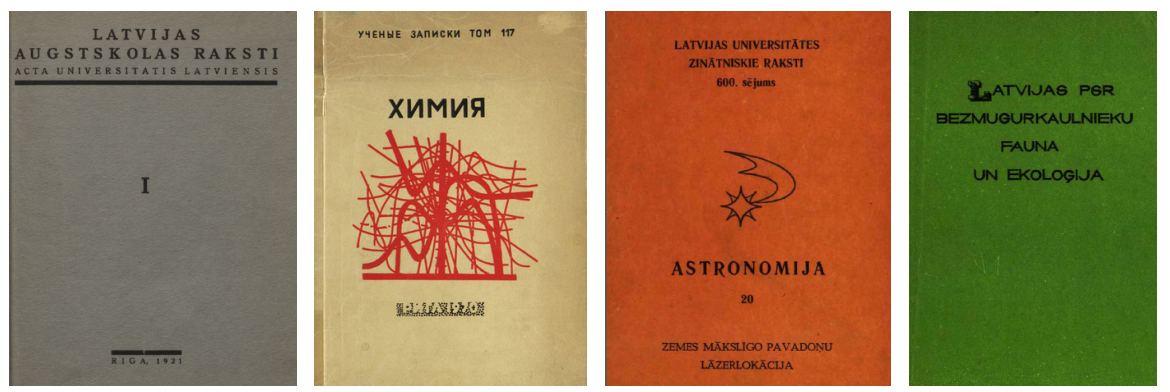

1. attēls. Digitalizēto LU Rakstu krājumu vāki

Repozitorijs ir tiešsaistes vietne (http://dspace.lu.lv/dspace/), kas nodrošina vienotu vidi LU intelektuālā darba rezultātu - dažāda veida dokumentu - publicēšanai, deponēšanai (pašarhivēšanai), ilglaicīgai saglabāšanai un padara tos pieejamus jebkurai pētniecības institūcijai un lietotājiem visā pasaulē. Repozitorijs ietver dažādus izdevumu veidus: žurnālu rakstus, grāmatas, rakstu krājumus, mācību materiālus, zinātṇu doktora disertācijas, maǵistra, bakalaura un kvalifikācijas darbus un citus materiālus, kā arī atspoguḷo LU struktūrvienību izdevējdarbību, tostarp LU Rakstu sērijas laidienus.

Repozitorijā ir arhivētas 944 LU Rakstu sērijas krājumu vienības, kas aptver plašu zinātņu nozaru spektru, bet ar atšķirīgu izdoto vienību skaitu (2. att.). $44 \%$ no visiem krājumiem aptver eksaktās zinātnes un dabaszinātnes, $29 \%$ - sociālās zinātnes, $22 \%$ - humanitārās zinātnes. 


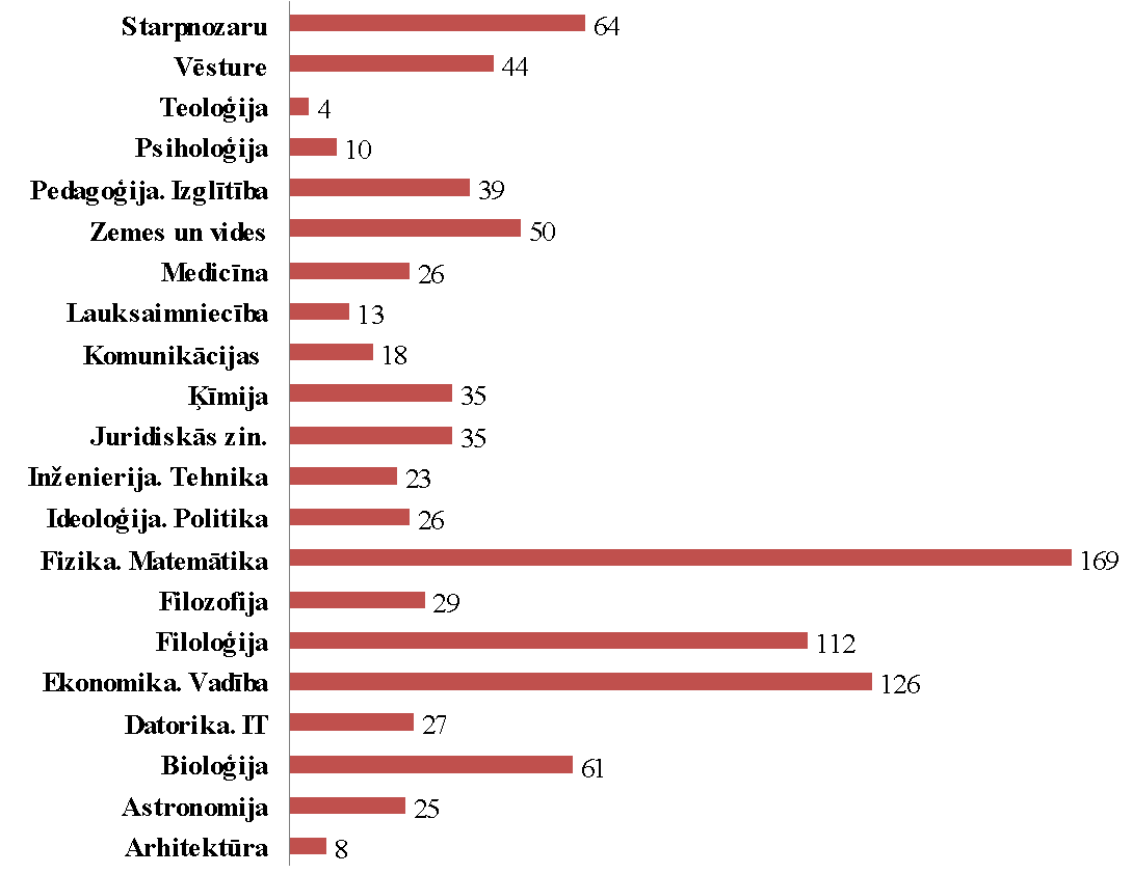

2. attēls. LU e-resursu repozitorijā ievietoto LU Rakstu sērijas vienību sadalījums pa nozarēm

LU Rakstiem repozitorijā ir izveidota atsevišķa komūna (repozitorija terminologijiā tā apzīmē augstākā līmeṇa struktūrvienību, kurai var būt pakārtotas apakškomūnas un/vai kolekcijas) "Universitātes Raksti / Acta Universitatis Latviensis / Scientific papers" (turpmāk - "Universitātes Raksti”) (3. att.) [6]. Pēc hronologiskā principa vecākajiem rakstu krājumiem komūnā ir izveidota kolekcija Latvijas Augstskolas Raksti (1921-1923), bet tiem sekojošais periods ir sadalīts 2 apakškomūnās: Latvijas Universitātes Raksti (1923-1943) un Latvijas Universitātes Raksti (1949-), kuras savukārt ir sadalītas daudzās kolekcijās.

Hronoloǵiski vecākajā kolekcijā Latvijas Augstskolas Raksti (1921-1923) ir ievietoti Latvijas Augstskolas 5 zinātnisko rakstu krājumi, kas izdoti laikā no 1921. līdz 1923. gadam [1]. Katrā sējumā ir sakopoti dažāda satura raksti bez īpašas tematiskās atlases. 


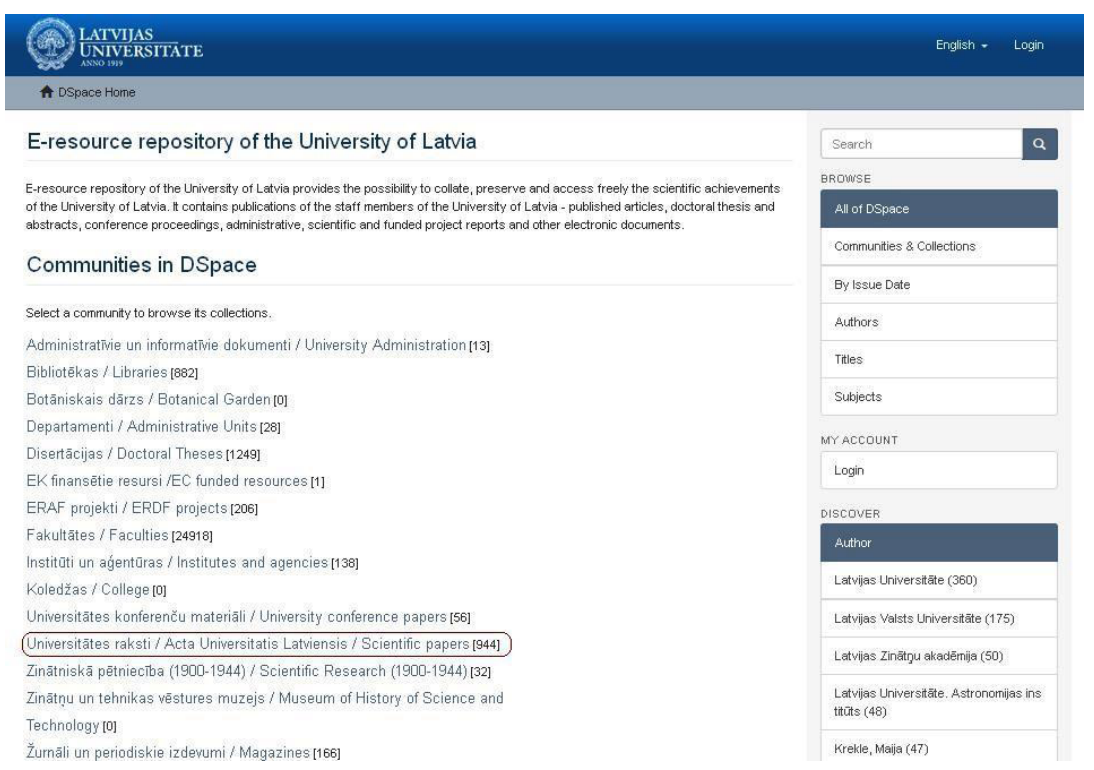

\section{3. attēls. LU e-resursu repozitorija sākumlapas saskarne}

Repozitorija apakškomūnā Latvijas Universitātes Raksti (1923-1943) ir ietverts 181 LU Rakstu krājums, kas aptver dažādas rakstu sērijas un ko veidojušas LU fakultātes un citas LU pētnieciskās struktūrvienības (4. att.). Krājumi ir sagrupēti pēc sērijām 19 kolekcijās. Vienā no tām ir sakopoti vecākie LU rakstu krājumi, kas tika izdoti bez sērijas. Katrā kolekcijā ietilpstošo vienību skaits redzams kvadrātiekavās aiz kolekcijas nosaukuma [2].

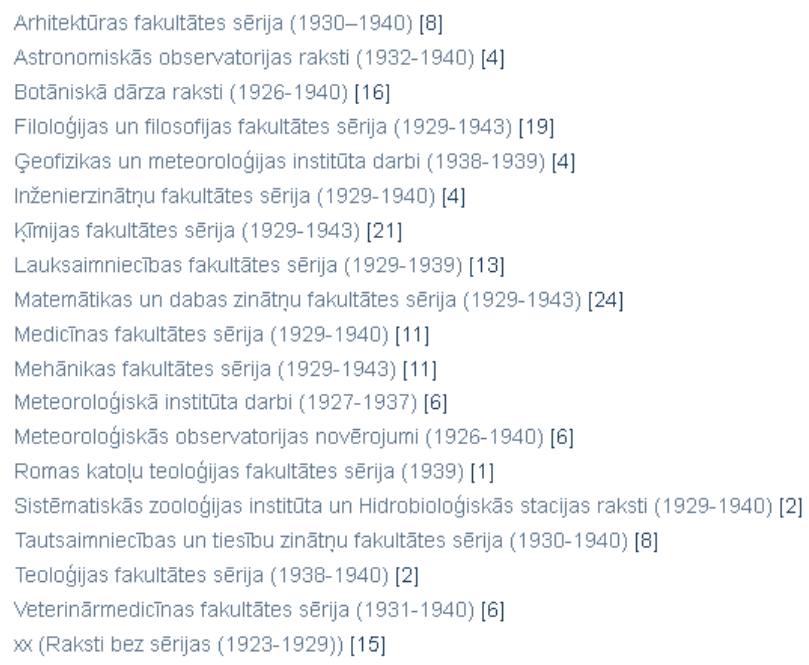

4. attēls. "Latvijas Universitātes Rakstu (1923-1943)" kolekcija 
Latvijas Universitātes Raksti (1949-) ir plašākā sadaļa repozitorijā, jo tajā ir iekḷauti 758 LU Rakstu krājumi, kas izdoti Universitātē no 1949. gada lìdz mūsdienām (5. att.). Tà kā LU Raksti šajā laika posmā tika izdoti gan daudzās sērijās, gan bez tām un lielākajai daḷai sēriju iekḷauto vienību skaits bija neliels, tad krājumi šajā apakškomūnā ir strukturēti pa zinātṇu nozarēm 21 kolekcijā [3].

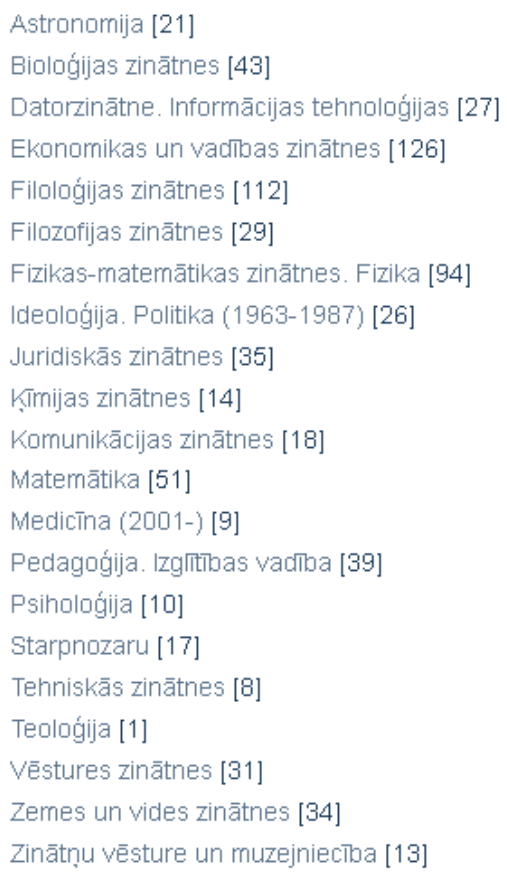

5. attēls. “Latvijas Universitātes Rakstu (1949-)” kolekcija

Repozitorijā ir ievietotas LU Rakstu krājumu pilntekstu datnes (PDF formātā), kuru saturs ir brīvi pieejams jebkuram interesentam.

Katram krājumam ir izveidoti starptautiskajiem standartiem (Dublin Core, OAI-PMH) atbilstoši metadati, t. i., dati par datiem (autors, nosaukums, publicēšanas datējums, nozare, atslēgvārdi u. c. informācija), kas nodrošina dažādu starptautisku repozitoriju un meklētājprogrammu sadarbību, tīklošanu un plašu resursu izmantošanu.

Meklēšanai repozitorija saskarnē var izmantot vienkāršo meklēšanu (Search DSpace sadaļa) vai paplašināto meklēšanu (Advanced Search) (6. att.). Abos veidos meklēt var visā repozitorija saturā (All of Space) vai konkrētā, lietotāja izvēlētā komūnā vai kolekcijā (piemēram, "Latvijas Universitātes Raksti (1949-)") pēc autora vai nosaukuma, vai atslēgvārda. 


\begin{tabular}{l} 
Search \\
C Search DSpace \\
This Community \\
BROư'sE \\
\hline All of DSpace \\
Communities \& Collections \\
\hline By Issue Date \\
\hline Authors \\
\hline Titles \\
\hline Subjects
\end{tabular}

\section{6. attēls. Meklēšana un pārlūkošana repozitorija saskarnē}

Repozitorija atvērtā programmatūra l̦auj tā saturu brīvi indeksēt, tāpēc informāciju par tajā ievietotām publikācijām un to saturu var meklēt, izmantojot meklētājprogrammas: gan iecienīto Google, gan akadēmiskās atvērtās piekḷuves meklētājprogrammu BASE, gan citas. Ja Google meklējamai izteiksmei pievieno parametru Site:dspace.lu.lv, tad rezultātus iegūstam tikai no repozitorija (7. att.).

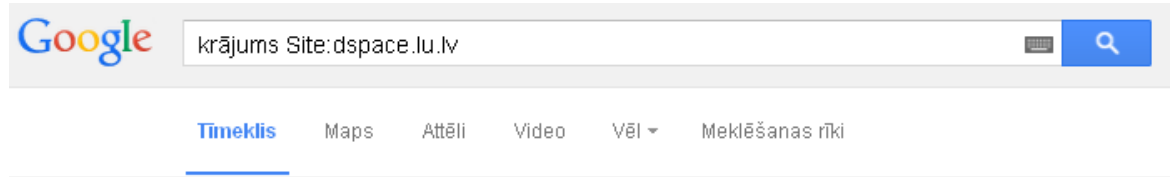

Aptuveni 330 rezultāti $(0,61$ sekundes)

Moderno tehnoloǵiju un atbilstošu interneta resursu ...

https://dspace.Iu.Iv/dspace/handle/7/15453 -

autors I Bračule - 2012

URI: https:/idspace.lu.Vidspace/handle/7/15453 ... resursu izmantošana var

veicināt tematiskā vārdu krājuma efektīvu apgūšanu angḷu valodas stundās.

Universitātes raksti / Acta Universitatis Latviensis / Scientific .

https://dspace.Iu.Ividspace/handle/7/14 -

Latvijas Valsts universitātes rakstu krājumi (1965-1991) / Сборники трудов ..

Latvijas Universitāte (LU Akadēmiskais apgāds, 2014). Latvijas ... Search DSpace.

Bibliotēka kā universitātes informācijas un mācību telpa

https://dspace.Iu. Iv/dspace/handle/7/2329 -

autors R Garklāva - 2014

2014. gada 30. janv - URI: https:ildspace .Iu.Ividspace/handle/7/2329 ... un

bibliotēku darba profesionālu rakstu kopīgais krājums atspogulo bibliotēku un

informācijas...

\section{7. attēls. Meklēšanas piemērs interneta vietnē Google}


Repozitorija vai izvēlētās kolekcijas saturu var arī pārskatìt pa komūnām un kolekcijām (Communities \& Collections) pēc kāda no parametriem (autora, nosaukuma, priekšmeta/atslēgvārda, publicēšanas datējuma) vai izmantojot komūnas vai kolekcijas "top 10" - autoru, priekšmetu/atslēgvārdu un hronologiskā perioda sarakstu.

Piekḷūt pie repozitorijā ievietoto LU Rakstu krājumu satura iespējams arī no Valsts nozīmes bibliotēku elektroniskā kopkataloga un LU zinātnisko publikāciju un vēstures datubāzes, jo LU Rakstu krājumu aprakstiem ir pievienotas saites uz šis informācijas vietnes datnēm.

Meklēšanas statistika parāda, ka 2015. gadā informācijas meklēšanai komūnā "Universitātes Raksti" visbiežāk ir izmantoti šādi atslēgvārdi [4]:

- autoriem: Latvijas Universitāte vai Latvijas Valsts universitāte;

- priekšmetiem/atslēgvārdiem: kīmija, filolog̣ija, Natural Sciences, Social Sciences, Humanities and Religion;

- publicēšanas datējumu periodam: 1990-1999, 2000-2009, 1970-1979.

Ikvienam repozitorija lietotājam ir pieejama izmantošanas statistika skatījumu skaits gan par repozitorija visām vienībām kopā, gan par atsevišķu struktūrvienību (komūnu/apakškomūnu/kolekciju), gan par konkrētu rakstu krājumu (repozitorijā nav arhivēti LU Rakstu sērijas krājumos iekḷautie raksti).

Turpinājumā apskatīsim LU Rakstu krājumu izmantošanas statistiku par laika posmu no 2014. gada marta līdz 2015. gada augustam. LU Rakstu krājumu skatījumu kopskaits šajā periodā ir 5984. Procentuāli lielākais skatījumu rādītājs - $42 \%$ - ir plašāk pārstāvētajās eksaktajās zinātnēs un dabaszinātnēs, tām seko sociālās zinātnes (25\%), humanitārās zinātnes (19\%) un starpnozaru krājumu (14\%) skatijjumi (8. att.).

$\square$ Eksaktās un dabas zin. $\square$ Humanitārās zin. $\square$ Sociālās zinātnes $\square$ Starpnozaru

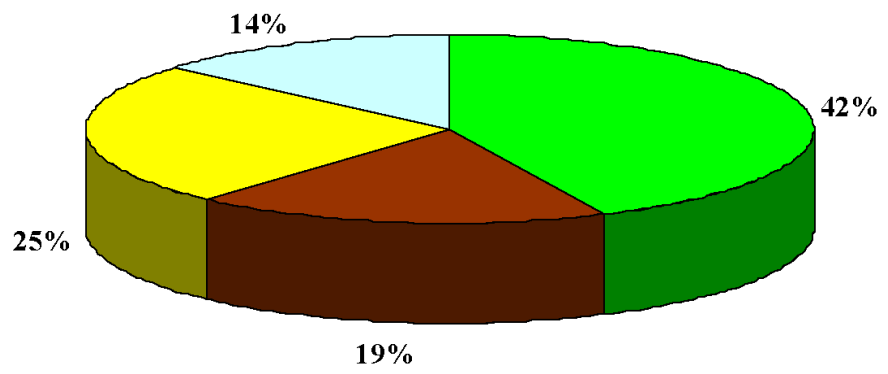

8. attēls. LU Rakstu krājumu vienību skatijumi repozitorijā 
Vidējais LU Rakstu sērijas krājumu skatījumu skaits ir 6,34 reizes, pa nozaru grupām: 6 - eksaktajām zinātnēm un dabaszinātnēm, 5,85 - sociālajām zinātnēm, 5,63 - humanitārajām zinātnēm un 12,69 - starpnozaru krājumiem. Skatijumu statistika pa zinātnes nozarēm uzskatāmi atspoguḷota 9. attēlā. Lielākais skatījumu skaits ir starpnozaru (812) un vēstures nozares (510) krājumiem (5). Augstākais vidējais skatījums ir teolog̣ijas $(19,5)$ un arhitektūras $(17,5)$ nozares krājumiem, kuru skaits ir neliels. Turpinājumā apskatīsim repozitorijā izveidoto LU Rakstu sadaļu izmantošanu.

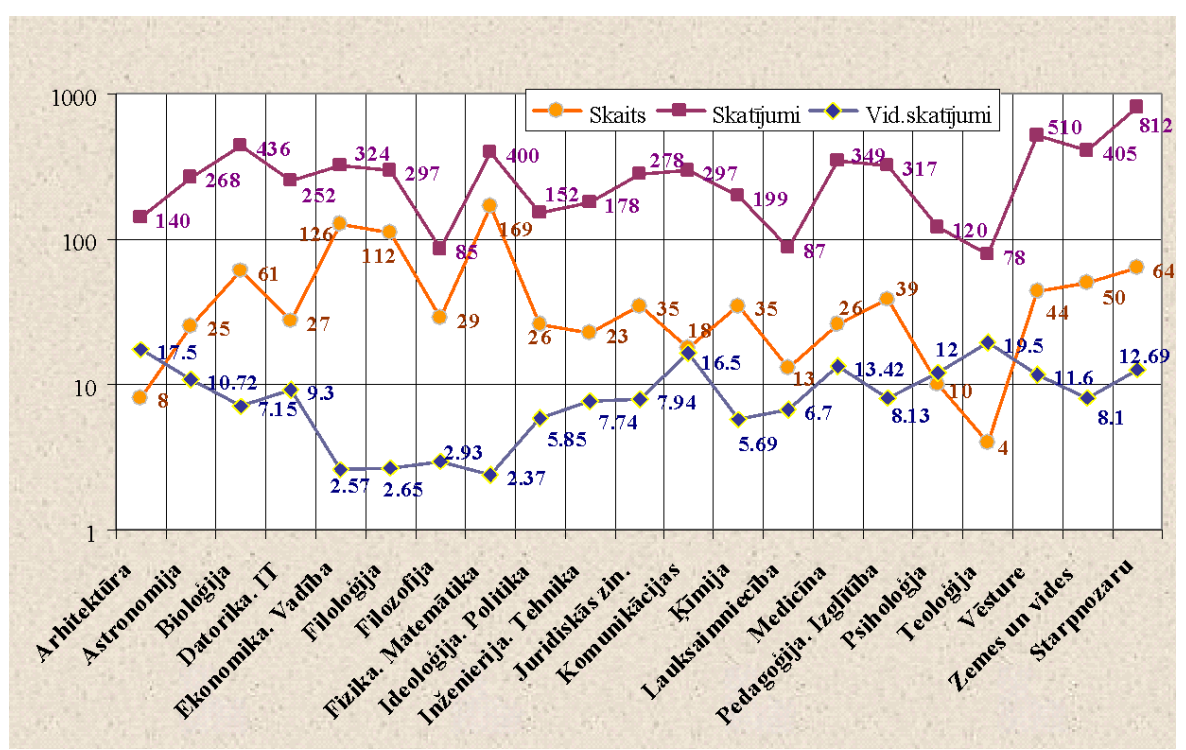

9. attēls. LU Rakstu vienību un skatījumu skaits pa zinātņu nozarēm

Komūna "Universitātes Raksti" minētā pusotra gada laikā ir skatīta 2825 reizes. Lielākais skatijumu skaits mēnesī - 222 reizes (2014. gada marts). Komūnas saturu pārsvarā ir skatījuši lietotāji no Latvijas (94\%), salīdzinoši nedaudz skatijumu ir no Igaunijas (2\%), Krievijas, ASV (pa 1\%) un citām valstīm (2\%) [5].

Repozitorija kolekcijas "Latvijas Augstskolas Raksti (1921-1923)" skatījumu skaits aplūkojamā pusotra gada periodā bija 177 reizes. Šis rādītājs un nelielais vienību skaits kolekcijai ir nodrošinājis augstāko vidējo vienības skatījuma rādītāju (35,4 reizes) starp visām LU Rakstu krājumu kolekcijām. Skatītākais šajā kolekcijā ir "Latvijas Augstskolas Rakstu" 1. sējums - 111 skatījumi.

Repozitorija struktūras apakšvienības "Latvijas Universitātes Raksti (1923-1943)" skatijjumu skaits iepriekš minētajā laika posmā ir 480 reizes, 
bet vidējais vienas vienības skatijums ir 2,66 reizes. Visvairāk skatīta ir Arhitektūras fakultātes sērijas kolekcija - 140 skatījumi, bet augstākais vidējā skatỉjuma radītājs (78 skatījumi) ir kolekcijai "Romas katoḷu teoloǵijas fakultātes sērija", kurā ietilpst tikai viens krājums. Šajā LU rakstu sadạ̣ā "Meteorolog̣ijas Institūta darbi" ir atrodams skatītākais LU Rakstu krājums "Baumanis, J. (1935) Pirmie Latvijas gaismas klimata pētijumi”, kas 2015. gada 1. pusgadā ir izmantots 218 reizes (10. att.).

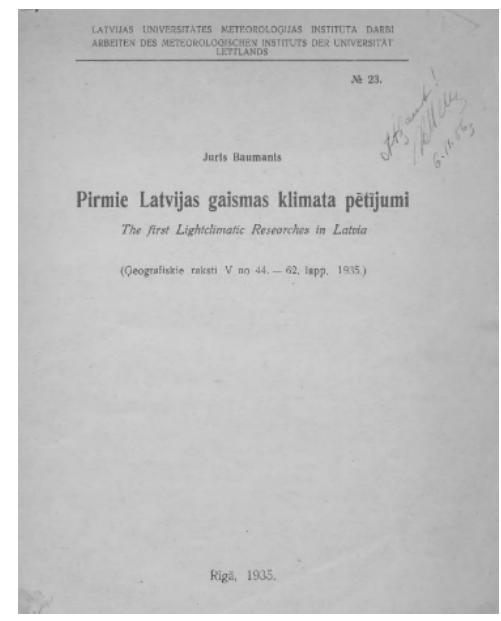

10. attēls. Skatītākais LU Rakstu krājums repozitorijā

"Latvijas Universitātes Raksti (1949-)" skatijumu kopskaits apskatāmajā periodā ir 1706, vidējais vienības skatijumu skaits - 2,26 reizes. Skatītākā ir teologijas kolekcija (82 skatijumi).

LU e-resursu repozitorijā apkopotie LU Rakstu sērijas krājumi atspoguļo LU zinātniskās darbības rezultātus un izdevējdarbību dažādos tās vēstures posmos, nodrošina krājumu pilnteksta datņu ilglaicīgu saglabāšanu un paplašina piekḷuves iespējas rakstu saturam. Informāciju par repozitorijā ievietotajiem krājumiem var meklēt ne tikai repozitorijā, bet arī izmantojot meklētājprogrammas, piemēram, Google vai citas. Saites uz repozitorijā pieejamo pilntekstu ir pievienotas rakstu krājumu aprakstiem Valsts nozīmes bibliotēku elektroniskajā kopkatalogā un LU zinātnisko publikāciju un vēstures datubāzē. LU Rakstu sējumu krājumu piekḷuves paplašināšana ne tikai sniedz iespēju zinātniskās darbỉbas rezultātu izmantošanai un novērtēšanai, bet arī veicina $L U$ atpazīstamību. 


\section{IZMANTOTIE INFORMĀCIJAS AVOTI}

1. Latvijas Augstskolas Raksti (1921-1923). University of Latvia. URL: http://dspace. lu.lv/dspace/handle/7/849

2. Latvijas Universitātes Raksti (1923-1943). University of Latvia. URL: http://dspace. lu.lv/dspace/handle/7/828

3. Latvijas Universitātes Raksti (1949-). University of Latvia. URL: http://dspace.lu.lv/ dspace/handle/7/1887

4. Search Statistics for Universitātes Raksti / Acta Universitatis Latviensis / Scientific papers. University of Latvia. URL: https://dspace.lu.lv/dspace/handle/7/14/searchstatistics

5. Statistics: Universitātes Raksti / Acta Universitatis Latviensis / Scientific papers. URL: http://dspace.lu.lv/dspace/handle/7/14/statistics

6. Universitātes Raksti / Acta Universitatis Latviensis / Scientific papers. URL: http:// dspace.lu.lv/dspace/handle/7/14 